\title{
Diagnosis of subclinical mastitis in Santa Inês and Morada Nova sheep in southeastern Brazil
}

\author{
Luiz Francisco Zafalon $^{1}$ (D) - Raul Costa Mascarenhas Santana ${ }^{1}$ - Lucas Eduardo Pilon ${ }^{2}$. \\ Guilherme Aparecido Fim Júnior ${ }^{2}$
}

Received: 23 September 2015 / Accepted: 14 March 2016 / Published online: 19 March 2016

(C) Springer Science+Business Media Dordrecht 2016

\begin{abstract}
The objective of this study was to evaluate different screening limits for the California mastitis test (CMT) and the somatic cell count (SCC) in previous diagnoses of subclinical mastitis in Santa Inês and Morada Nova ewes, which were reared under the same management conditions. Additionally, cutoff points were defined for SCC in accordance with the sensitivity and specificity of the test. A total of 907 mammary halves were subjected to CMT and SCC. The disease was confirmed by means of microbiological identification. Coagulase-negative staphylococci (CNS) were the microorganisms with highest occurrence. The CMT score of 1+ provided adequate sensitivity and specificity at all periods of lactation investigated. This score showed good agreement with SCC, $>400,000$ cells $\mathrm{mL}^{-1}$. Higher cell counts favored higher diagnostic specificity. They can be used when producers have financial difficulties relating to treatment or culling of sheep with subclinical mastitis. However, producers should be warned about the risk of false-negative results in the flock.
\end{abstract}

Keywords Diagnostic tests $\cdot$ Subclinical mastitis $\cdot$ Sheep · Milk

Luiz Francisco Zafalon

luiz.zafalon@embrapa.br

1 Brazilian Agricultural Research Corporation (EMBRAPA), Embrapa Southeast Livestock, Rod. Washington Luís, Km 234, Caixa Postal 339, 13560-970 São Carlos, SP, Brazil

2 Postgraduate Program in Veterinary Medicine, School of Agricultural and Veterinarian Sciences, UNESP - Univ Estadual Paulista,

Via de Acesso Prof. Paulo Donato Castellane, s/n,

14884-900 Jaboticabal, SP, Brazil

\section{Introduction}

Mastitis limits the economic exploitation of sheep for meat production due to losses in the development of lambs or the lifespan of ewes (Marogna et al. 2010). Ovine subclinical mastitis is characterized by quantitative and qualitative changes to milk, mainly through increased numbers of somatic cells. This higher cell count is due to mammary infections caused predominantly by staphylococci (Bergonier and Berthelot 2003). Indirect tests such as the California mastitis test (CMT) (Hawari et al. 2014) and the somatic cell count (SCC) (Spanu et al. 2011) are among the methods most frequently used for diagnosing subclinical mastitis based on the increase in the number of somatic cells in milks from affected halves. According to Nunes et al. (2008), few studies have addressed the diagnosis of subclinical mastitis in sheep breeds for meat production under Brazilian conditions.

The CMT presents limitations when applied to sheep, since it was originally developed for cows (Schalm and Noorlander 1957). Moreover, its subjective nature may lead to the incorrect interpretation of results (Clements et al. 2003). The SCC, on the other hand, is an indicator of mammary gland health in cows and sheep (Spanu et al. 2011) and can be used to monitor prevalence of subclinical mastitis (Sharma et al. 2011). The SCC in sheep milk covers different cellular elements, such as leukocytes and epithelial cells (Blagitz et al. 2013).

There is no consensus in the literature about the acceptance of any SCC value as normal in sheep mammary halves. The objective of this study was to evaluate the different screening limits for the CMT and SCC of sheep for meat production with previously diagnosed mastitis, under Brazilian conditions of management. The cutoff points were defined for SCC according to diagnostic sensitivity and specificity. 


\section{Materials and methods}

\section{Management and milk samples}

Sampling was carried out in two flocks located in the central region of the state of São Paulo, southeastern Brazil, between June 2012 and October 2013. The infectious etiology of subclinical mastitis was investigated in 907 mammary halves in Santa Inês and Morada Nova sheep. These ewes were subjected to the same semi-intensive management system, with access to pasture during the day and yarding in covered shelter at night. Milk samples were collected after clinical examination of the mammary gland to confirm the absence of clinical signs of disease. The samples were collected from each mammary half for the CMT, and plastic flasks containing $60 \mathrm{~mL}$ of milk with bronopol preservative were prepared for an electronic SCC. Antisepsis of the teats was performed using isopropyl alcohol, and two samples of approximately $5 \mathrm{~mL}$ of milk were collected from each mammary half. These samples were placed in sterile glass tubes for microbiological testing. This procedure was carried out after the CMT and prior to the SCC. The samples were collected at different postpartum times and immediately prior to weaning as follows: within 14 days of lambing; 15-28 days after lambing; 29-46 days after lambing; and not more than 10 days before weaning.

\section{CMT and SCC readings}

CMT readings were performed after mixing $2 \mathrm{~mL}$ of milk from each mammary half with the same amount of reagent. After slight homogenization, the samples were classified according to the degree of viscosity. Samples subjected to SCC were forwarded to a reference laboratory for milk quality recognized by the Brazilian Ministry of Agriculture, Livestock, and Food Supply, where count procedures were conducted in an electronic device by means of flow cytometry. The results of CMT were classified into four distinct degrees of viscosity: negative, weakly positive $(1+)$, positive $(2+)$, or strongly positive $(3+)$. Different cutoffs of SCC results (cells $\mathrm{mL}^{-1}$ ) were defined: 100,000; 200,000; 300,000; 400,000; and 500,000.

\section{Microbiological diagnosis}

A microbiological diagnosis of subclinical mastitis was made after observing bacterial growth on the surface of Petri dishes containing solid culture media plus defibrinated sheep blood (5\%) and MacConkey agar. The plates were incubated under aerobic conditions for up to $72 \mathrm{~h}$ at $37{ }^{\circ} \mathrm{C}$, with readings at intervals of $24 \mathrm{~h}$. The macroscopic characteristics of the colonies were evaluated, such as morphology, pigment production, and hemolysis. Microorganisms were identified based on morphological, staining, and biochemical characteristics. The results of the microbiological tests were interpreted as described by Pradieé et al. (2012).

\section{Correlation and cutoff points analyses}

The correlation between the CMT and the SCC was evaluated based on calculated kappa coefficients, with values ranging from -1 to 1 (Sim and Wright 2005). The values were interpreted as described by Viera and Garrett (2005): $<0$, less than chance agreement; 0.01-0.20, slight agreement; $0.21-$ 0.40 , fair agreement; $0.41-0.60$, moderate agreement; $0.61-$ 0.80 , substantial agreement; and 0.81-0.99, almost perfect agreement.

Different cutoff points for the SCC were calculated, with respective accuracies defined by the areas under the receiver operating characteristic (ROC) curve (Greiner et al. 2000), according to the postpartum time when samples were collected from the sheep. Diagnostic sensitivity was established as the ability of the tests to present a positive result in the presence of microbiological isolation, while specificity was established when the tests showed negative results in the absence of microorganisms. The diagnostic sensitivity of SCC was analyzed separately in order to establish different cutoff points, which were called "cutoff point A." These cutoff points were compared with those calculated using Youden's $\mathrm{J}$ index, which is given by the sum of sensitivity and specificity, minus one, and is used to define optimal thresholds in diagnostic tests (Schisterman et al. 2005). The purpose of cutoff point A was to establish higher diagnostic sensitivity for SCC in screening for subclinical mastitis in sheep, while cutoff point J, provided by Youden's index, do not necessarily favor sensitivity in the test. These values reflect the relationship between the rate of truly positive results and the rate of false-positive values, i.e., a combination of sensitivity and specificity values for the test. The results may range from 0.5 to 1.0 . Results close to 0.5 indicate that the test does not provide an accuracy rating better than chance. The closer a value is to 1.0 the greater the accuracy of the test will be (Greiner et al. 2000). The calculations were performed with using an online tool provided by the AusVet Animal Health Services (2014).

\section{Results}

Table 1 describes the infectious etiology of subclinical mastitis. No differences were observed in susceptibility to disease at any of the times evaluated, with relative risks of 1.283 $(P=0.5043), 1.015(P=1.00), 0.8111(P=0.7526)$, and $1.014(P=1.00)$, respectively, for within 14 days of lambing; 15-28 days after lambing; 29-46 days after lambing; and not more than 10 days before weaning. 
Table 1 Etiological agents of subclinical mastitis in mammary halves of Santa Inês and Morada Nova ewes

\begin{tabular}{|c|c|c|c|c|c|c|}
\hline \multirow[t]{2}{*}{ Microorganisms } & \multicolumn{2}{|c|}{ Santa Inês ewes } & \multicolumn{2}{|c|}{ Morada Nova ewes } & \multicolumn{2}{|c|}{ Total } \\
\hline & $N$ & $\%$ & $N$ & $\%$ & $N$ & $\%$ \\
\hline Coagulase-negative staphylococci & 73 & 14.0 & 61 & 15.8 & 134 & 14.8 \\
\hline Enterobacteria & 23 & 4.4 & 11 & 2.8 & 34 & 3.8 \\
\hline Streptococcus spp. & 15 & 2.8 & 11 & 2.8 & 26 & 2.9 \\
\hline Staphylococcus aureus & 7 & 1.3 & 12 & 3.1 & 19 & 2.1 \\
\hline Micrococcus spp. & 5 & 1.0 & 3 & 0.8 & 8 & 0.9 \\
\hline Corynebacterium spp. & 3 & 0.6 & 3 & 0.8 & 6 & 0.6 \\
\hline Streptococcus spp. $+\mathrm{CNS}^{\mathrm{a}}$ & 3 & 0.6 & 0 & 0.0 & 3 & 0.3 \\
\hline Yeasts & 2 & 0.4 & 0 & 0.0 & 2 & 0.2 \\
\hline Coagulase-positive staphylococci & 1 & 0.2 & 1 & 0.3 & 2 & 0.2 \\
\hline CNS + yeasts & 1 & 0.2 & 0 & 0.0 & 1 & 0.1 \\
\hline Streptococcus spp. + enterobacteria & 0 & 0.0 & 1 & 0.3 & 1 & 0.1 \\
\hline Negative samples & 389 & 74.5 & 282 & 73.2 & 671 & 74.0 \\
\hline Total & 522 & 100.0 & 385 & 100.0 & 907 & 100.0 \\
\hline
\end{tabular}

${ }^{\text {a }}$ CNS Coagulase-negative staphylococci
Table 2 describes the diagnostic sensitivity and specificity values for the various scores of the CMT and the enumeration limits in the SCC, according to the postpartum sampling time. Microorganisms were identified in milk samples from 236 (26.0\%) of the 907 mammary halves examined. The distribution of positive mammary halves in the two breeds was similar: $25.5 \%$ for Santa Inês and $26.8 \%$ for Morada Nova. The predominant etiological agents were coagulase-negative staphylococci (CNS). These microorganisms were responsible for infections in 134/236 (56.8\%) of the mammary halves

Table 2 Diagnostic characteristics (\%) of different scores from the California mastitis test and the enumeration limits for somatic cells (cells $\mathrm{mL}^{-1}$ ) for the identification of subclinical mastitis in sheep at different times after lambing

Diagnostic methods Periods

\begin{tabular}{|c|c|c|c|c|c|c|c|c|}
\hline & \multicolumn{2}{|c|}{$1-14$ days } & \multicolumn{2}{|c|}{ 15-28 days } & \multicolumn{2}{|c|}{ 29-46 days } & \multicolumn{2}{|c|}{ Weaning } \\
\hline & Sen & Spe & Sen & Spe & Sen & Spe & Sen & Spe \\
\hline $\mathrm{MT}^{\mathrm{a}}($ & 3.9 & 75.0 & 82.4 & 72.2 & 84.2 & 70.6 & 75.0 & 76.7 \\
\hline CMT ( & 0 & 80.6 & 56.9 & 78.9 & 52.6 & 82.4 & 55.6 & 93.1 \\
\hline CMT (3+) & 48.4 & 91.7 & 37.3 & 88.9 & 36.8 & 85.3 & 41.7 & 95.5 \\
\hline $\mathrm{SCC}^{\mathrm{b}}>100,000$ & 96.6 & 36.2 & 98.0 & 34.8 & 100.0 & 38.7 & 92.4 & 35.4 \\
\hline$S C C>200,000$ & 86.2 & 52.2 & 96.0 & 55.1 & 88.9 & 45.2 & 85.9 & 62.6 \\
\hline$S C C>300,000$ & 86.2 & 62.3 & 94.0 & 62.9 & 77.8 & 51.6 & 76.1 & 72.0 \\
\hline $\mathrm{CC}>400,000$ & 86.2 & 68.1 & 84.0 & 67.4 & 77.8 & 61.3 & 70.6 & 77.8 \\
\hline $\mathrm{SCC}>500,000$ & 82.8 & 69.6 & 80.0 & 70.8 & 72.2 & 64.5 & 66.3 & 81.9 \\
\hline
\end{tabular}

Sen Sensitivity, Spe Specificity

${ }^{\text {a }}$ CMT California mastitis test; $(1+),(2+)$, and $(3+)=$ intensity of positive reaction to CMT

${ }^{\mathrm{b}} \mathrm{SCC}$ Somatic cell count (cells $\mathrm{mL}^{-1}$ ) separately. Taking into account all the staphylococcal species and associations with other microorganisms, this percentage increased to $67.4 \%$.

Table 3 describes the agreement between different degrees of reaction to CMT and the SCC values. The CMT score of 1+ presented higher than $70 \%$ sensitivity and specificity in the screening of subclinical mastitis in sheep at all the sampling times. The CMT scores of $2+$ and $3+$ presented higher specificity than the score of $1+$, but lower sensitivity. The CMT score of $2+$ showed higher than $70 \%$ sensitivity only for the sampling time within 14 days of lambing, but was lower than $60 \%$ at the other times. Lower sensitivities were found for the score of $3+$. Specificity showed a tendency to increase with increasing SCC. At weaning, the sensitivity to $\mathrm{SCC}>500,000$ cells $\mathrm{mL}^{-1}$ was the lowest $(66.3 \%)$. Counts exceeding 400 , 000 cells $\mathrm{mL}^{-1}$ were able to maintain sensitivities exceeding $70 \%$ at all the sampling times, but specificity was higher than $70 \%$ only at weaning. The same applies to the SCC $>300,000$ cells $\mathrm{mL}^{-1}$.

The cutoff points and accuracy of the SCC in diagnosing subclinical mastitis in sheep were established as shown in Table 4. The kappa indices showed values not exceeding 0.79 . The highest indices at the different times were found for CMT scores of $1+$ and SCC exceeding 400,000 cells $\mathrm{mL}^{-1}$. For the sampling time within 14 days of lambing, the index exceeded 0.70 with SCC higher than 300,000 cells $\mathrm{mL}^{-1}$ and CMT $1+$.

Accuracy rates were higher than 0.80 at all the sampling times. When the diagnostic context favored the sensitivity of the test, the values of the cutoff points for SCC were lower than those determined by using Youden's index, except for the sampling time of 15-28 days postpartum. However, at this time, the specificity was found to be 0.66 , despite the high 
Table 3 Kappa agreement between different California mastitis test (CMT) scores and cutoffs of somatic cell count (SCC) at different sampling time points

\begin{tabular}{ccllll}
\hline \multicolumn{7}{r}{ SCC 100,000 } & SCC 200,000 & SCC 300,000 & SCC 400,000 & SCC 500,000 \\
\hline \multicolumn{2}{l}{ Within 14 days of lambing } & & & & \\
CMT (1+) & 0.41 & 0.66 & 0.77 & 0.79 & 0.79 \\
CMT (2+) & 0.31 & 0.51 & 0.65 & 0.71 & 0.74 \\
CMT (3+) & 0.16 & 0.29 & 0.38 & 0.42 & 0.45 \\
15-28 days after lambing & & & & \\
CMT (1+) & 0.37 & 0.61 & 0.66 & 0.71 & 0.75 \\
CMT (2+) & 0.26 & 0.47 & 0.54 & 0.66 & 0.73 \\
CMT (3+) & 0.14 & 0.26 & 0.31 & 0.39 & 0.44 \\
29-46 days after lambing & & & & \\
CMT (1+) & 0.45 & 0.62 & 0.58 & 0.70 & 0.79 \\
CMT (2+) & 0.25 & 0.36 & 0.40 & 0.50 & 0.57 \\
CMT (3+) & 0.17 & 0.25 & 0.34 & 0.42 & 0.48 \\
Within 10 days from weaning & & & & 0.69 \\
CMT (1+) & 0.33 & 0.61 & 0.69 & 0.73 & 0.62 \\
CMT (2+) & 0.14 & 0.32 & 0.45 & 0.54 & 0.48 \\
CMT (3+) & 0.10 & 0.23 & 0.34 & 0.41 & \\
\hline
\end{tabular}

sensitivity $(0.92)$ of the cutoff point J. It was noted that, starting from the time of 29 days postpartum, the cutoff points decreased as the sheep approached the weaning period, i.e., 280,000 and 262,000 cells $\mathrm{mL}^{-1}$. The specificity of the test at the sampling time of 29-46 days was low (0.52). Despite the specificity of 0.84 conferred by Youden's index, the sensitivity was not as high (0.67).

\section{Discussion}

Morada Nova is a locally adapted breed reared mainly in Brazil's northeastern region. It is used for meat and hide production and presents with good fertility and prolificacy, even in the harsh conditions of the semi-arid region (Shiotsuki et al. 2014). The Santa Inês breed, which is widely reared throughout Brazil, presents with good reproductive capacity and good milk production, particularly in regions with a mild climate and greater availability of food (Pereira et al. 2014). The occurrence of subclinical mastitis in the two breeds was similar. We believe that this similarity stems from the fact that the animals were raised under the same management conditions.

The occurrence rate of subclinical mastitis was lower than that reported by Moroni et al. (2007) (51.1\%), but was similar to that found by Davasaztabrizi et al. (2013) (20.3\%). Our findings corroborate those of other studies that reported the presence of CNS in most cases of subclinical mastitis in sheep bred for meat (Moroni et al. 2007; Santana et al. 2013; Pereira et al. 2014; Olechnowicz and Jaskowski 2014). There is little information that clarifies why CNS are the most important agents of subclinical mastitis in sheep, but their antimicrobial resistance profile and production of biofilms have been described (Ergun et al. 2012). These two features may be interconnected and favor the maintenance of microorganisms in sheep mammary glands and the consequent predominance of CNS in flocks. The ewes were moved to covered locations
Table 4 Cutoff points for the somatic cell count as a function of postpartum sampling time for the diagnosis of ovine subclinical mastitis

\begin{tabular}{|c|c|c|c|c|c|c|c|}
\hline \multirow[t]{2}{*}{ Periods } & \multicolumn{3}{|c|}{ Cutoff point $\mathrm{A}^{\mathrm{a}}$} & \multicolumn{3}{|c|}{ Cutoff point $\mathrm{J}^{\mathrm{b}}$} & \multirow[t]{2}{*}{ Accuracy $(95 \% \mathrm{CI})$} \\
\hline & $\mathrm{SCC}^{\mathrm{c}}$ & Sen & Spe & $\mathrm{SCC}$ & Sen & Spe & \\
\hline 1-14 days & 532 & 0.83 & 0.71 & 1133 & 0.76 & 0.81 & $0.833(0.747-0.918)$ \\
\hline 15-28 days & 565 & 0.80 & 0.74 & 325 & 0.92 & 0.66 & $0.841(0.777-0.905)$ \\
\hline 29-46 days & 280 & 0.83 & 0.52 & 1398 & 0.67 & 0.84 & $0.805(0.681-0.928)$ \\
\hline Weaning & 262 & 0.80 & 0.69 & 386 & 0.74 & 0.77 & $0.830(0.750-0.857)$ \\
\hline
\end{tabular}

Sen Sensitivity, Spe Specificity

${ }^{\text {a }}$ Cutoff point when the diagnostic context favored the sensitivity of the test

${ }^{\mathrm{b}}$ Cutoff point calculated by Youden's index

${ }^{\mathrm{c}}$ Somatic cell count $(\times 1000)$ 
during the daytime only when they underwent health management measures to control parasitic infections. However, although these locations were cleaned constantly, stools and dampness were always present. CNS species were not identified in this work; therefore, the prevalence of contagious or environmental CNS could not be established.

The sensitivity and specificity of the CMT and SCC may exceed $90 \%$. These values suffice to classify these tests as useful for screening subclinical mastitis, thus minimizing false-negative results (Lafi 2006). In this study, the CMT score of $1+$ proved ideal for use in screening ewes with subclinical mastitis. Nunes et al. (2008) also chose the CMT score of $1+$ as ideal to differentiate between healthy mammary glands and those affected by subclinical mastitis in Santa Inês sheep.

A decrease in the diagnostic sensitivity of $\mathrm{SCC}$ with higher values was also observed by Clements et al. (2003). However, unlike in our results, those authors observed that CMT scores of $3+$ optimized the sensitivity and specificity of the test, even with a sensitivity score of less than $70 \%$. In the present study, there were some cases of mammary halves with SCC higher than $1,000,000$ cells $\mathrm{mL}^{-1}$ and CMT results with higher scores, but showing negativity in the microbiological examination. The secretory epithelial desquamation can occur near the dry period of sheep. The inverse was also found to occur, i.e., cases of mammary halves with low SCC or negative to CMT, but with identification of microorganisms. None of these values were withdrawn from the analysis. Like cows, sheep may respond differently to intramammary infection and may even eliminate the infectious agent, but without reducing the intensity of the inflammatory response. Our microbiological analysis did not include an investigation of the etiological agents whose development requires specific culture media (e.g., Mycoplasma spp.). Possible fluctuations may occur in the SCC, depending on the microorganisms involved, the chronic or acute stage of infection, or the animal's stress (HARMON 1994).

Although this sampling time was defined as a range of time that involved milk samples collected from the first postpartum day onwards, the largest number of samples was collected after 7 days postpartum. There was a tendency for greater agreement with scores of $1+$ as the SCC increased in the mammary halves, although the kappa index at weaning was 0.69 between the CMT score of $1+$ and SCC $>500,000$ cells $\mathrm{mL}^{-1}$. A kappa index of 1 would represent perfect agreement. Zero would indicate agreement that was no better than what would be expected randomly. Negative kappa coefficients would indicate a lower agreement rate than what would be expected randomly (Sim and Wright 2005). The agreement rate between the CMT and SCC was higher than that found by Pradieé et al. (2012). However, these authors used a cutoff point of 500,000 cells $\mathrm{mL}^{-1}$. The lower agreement these authors reported $(k=0.152)$ was only higher than the correlation observed for the CMT score of $3+$ and $\mathrm{SCC}>100$, 000 cells $\mathrm{mL}^{-1}$ at the sampling time of $15-28$ days postpartum and for the scores of $2+$ and $3+$ and SCC $>100$, 000 cells $\mathrm{mL}^{-1}$ at weaning.

According to Berthelot et al. (2006), a gland can be considered to be free of mastitis when the SCC is less than 500 , 000 cells $\mathrm{mL}^{-1}$. On the other hand, a gland can be considered mastitic when the SCC is higher than $1,000,000$ or $1,200,000$ cells $\mathrm{mL}^{-1}$. Counts of 500,000 to $1,000,000$ cells $\mathrm{mL}^{-1}$ indicate suspected cases of subclinical mastitis, which require confirmation by means of bacteriological examination (Fragkou et al. 2014). The values shown in Table 4 were higher than the cutoff point suggested by Clements et al. (2003), which was $1,202,000$ cells $\mathrm{mL}^{-1}$ and for which the sensitivity and specificity were reported to be 72 and $63 \%$, respectively. However, the cutoff points calculated by Youden's index were close to this value when the sheep were in the first 2 weeks postpartum and 29-46 days postpartum $(1,113,000$ and $1,398,000$, respectively), with specificities of 0.81 and 0.84 and sensitivity close to the first SCC value (0.76).

According to Kern et al. (2013), the limit of 400,000 cells $\mathrm{mL}^{-1}$ would be the most suitable one for detecting problems of mastitis in sheep that are bred for meat production. The goals for raising sheep probably interfere with the detection of an ideal limit for SCC, as it pertains to the identification of animals with subclinical mastitis. Other authors reported counts of less than 400,000 cells $\mathrm{mL}^{-1}$ in a study of dairy sheep, ranging from 200,000 to 400,000 cells $\mathrm{mL}^{-1}$ (Olechnowicz and Jaskowski 2014). The establishment of suitable cutoff points to determine cases of subclinical mastitis in sheep bred for meat production should be in line with the costs that producers might incur. The use of a CMT score that is weakly positive $(1+)$ can be considered ideal for screening of subclinical mastitis in sheep of the Santa Inês and Morada Nova breeds. This score showed good agreement with the SCC of 400,000 cells $\mathrm{mL}^{-1}$ in flocks in which the predominant infectious etiology is CNS. Higher cell counts present good specificity and can be used by producers in financial constraints, within a context of treatment or culling of sheep. However, producers should be warned about the risk of false-negative results in the flock.

\section{Compliance with ethical standards}

Conflict of interest The authors declare that they have no conflict of interest.

Ethical approval All the procedures performed in studies involving animals were in accordance with the ethical standards of the institution where the studies were conducted. 
Funding São Paulo Research Foundation (Fapesp; Grant number 2012/03847-1).

\section{References}

Ausvet Animal Health Services. Calculate test Sensitivity and Specificity and ROC curves. 2014. http://epitools.ausvet.com.au/content.php? page $=$ ROC curves. Accessed 28 Aug 2014.

Berthelot, X., Lagriffoul, G., Concordet, D., Barillet, F., Bergonier, D., 2006. Physiological and pathological thresholds of somatic cell counts in ewe milk. Small Ruminant Research, 62, 27-31.

Bergonier, D. and Berthelot, X., 2003. New advances in epizootiology and control of ewe mastitis. Livestock Producion Science, 79, 1-16.

Blagitz, M.G., Batista, C.F., Gomes, V., Souza, F.N., Libera, A.M.M.P.D., 2013. Características físico-químicas e celularidade do leite de ovelhas Santa Inês em diferentes estágios de lactação. Ciência Animal Brasileira, 14, 454-461.

Clements, A.C.A., Taylor, D.J., Fitzpatrick, J.L., 2003. Evaluation of diagnostic procedures for subclinical mastitis in meat-producing sheep. Journal of Dairy Research, 70, 139-148.

Davasaztabrizi, A., Shafavi, O., Samimi, A., 2013. Prevalence of subclinical mastitis in ewe with somatic cell count procedure in Tabriz area of Iran. World Journal of Zoology, 8, 167-169.

Ergun, Y., Aslantas, O., Kireçci, E., Ozturk, F., Ceylan, A., Boyar, Y., 2012 Antimicrobial susceptibility. presence of resistance genes and biofilm formation in coagulase negative Staphylococci isolated from subclinical sheep mastitis. Kafkas Üniversitesi Veteriner Fakültesi Dergisi, 18, 449-456.

Fragkou, I.A., Boscos, C.M., Fthenakis, G.C., 2014. Diagnosis of clinical or subclinical mastitis in ewes. Small Ruminant Research, 118, 86-92.

Greiner, M., Pfeiffer, D., Smith, R.D., 2000. Principles and practical application of the receiver-operating characteristic analysis for diagnostic tests. Preventive Veterinary Medicine, 45, 23-41.

Harmon, R.J., 1994. Physiology of Mastitis and Factors Affecting Somatic Cell Counts. Journal of Dairy Science, 77, 2103-2112.

Hawari, A.D., Obeidat, M., Awaisheh, S.S., Al-Daghistani, H.I., Al-Abbadi, A.A., Omar, S.S., Qrunfleh, I.M., Al-Dmoor, H.M., El-Qudah, J., 2014. Prevalence of mastitis pathogens and their resistance against antimicrobial agents in Awassi sheep in Al-Balqa province of Jordan. American Journal of Animal and Veterinary Sciences, 9, 116-121.

Kern, G., Traulsen, I., Kemper, N., Krieter, J., 2013. Analysis of somatic cell counts and risk factors associated with occurrence of bacteria in ewes of different primary purposes. Livestock Science, 157, 597-604.

Lafi, S.Q., 2006. Use of somatic cell counts and California Mastitis Test results from udder halves milk samples to detect subclinical intramammary infection in Awassi sheep. Small Ruminant Research, 62, 83-86.

Marogna, G., Rolesu, S., Lollai, S., Tola, S., Leori, G., 2010. Clinical findings in sheep farms affected by recurrent bacterial mastitis. Small Ruminant Research, 88, 119-125.

Moroni, P., Pisoni, G., Varisco, G., Boettcher, P., 2007. Effect of intramammary infection in Bergamasca meat sheep on milk parameters and lamb growth. Journal of Dairy Research, 74, 340-344.

Nunes, G.R., Blagitz, M.G., Freitas, C.B., Souza, F.N., Ricciardi, M., Stricagnolo, C.R., Sanches, B.G.S., Azedo, M.R., Sucupira, M.C.A., Della Libera, A.M.M.P., 2008. Avaliação de indicadores inflamatórios no diagnóstico da mastite bovina. Arquivos do Instituto Biológico, 75, 271-278.

Olechnowicz, J. and Jaskowski J.M., 2014. Mastitis in small ruminants. Medycyna Weterynatyjna, 70, 67-72.

Pradieé, J., Moraes, C.R., Gonçalves, M., Vilanova, M.S., Corrêa, G.F., Lauz, O.G., Osório, M.T.M., Schmidt, V., 2012. Somatic cell count and California Mastitis Test as a diagnostic tool for subclinical mastitis in ewes. Acta Scientiae Veterinariae, 40, 1038-1044.

Pereira, P.F.V., Stotzer, E.S., Pretto-Giordano, L.G., Müller, E.E., Lisbôa, J.A.N., 2014. Fatores de risco, etiologia e aspectos clínicos da mastite em ovelhas de corte no Paraná. Pesquisa Veterinária Brasileira, 34, 1-10.

Santana, R.C.M., Zafalon, L.F., Esteves, S.N., Tanaka, E.V., Pilon, L.E., Massa, R., 2013. Occurrence of etiologic agents causing subclinical mastitis in Morada Nova and Santa Ines ewes. Ars Veterinária, 29, $148-152$.

Schalm, O.W. and Noorlander, D.O. 1957. Experiments and observations leading to development of the California mastitis test. Journal of the American Veterinary Medical Association, 130, 199-204

Sharma, N., Singh, N.K., Bhadwal, M.S., 2011. Relationship of somatic cell count and mastitis: an overview. Australas. Journal of Animal Science, 24, 429-438.

Schisterman, E.F., Perkins, N.J., Liu, A., Bondell, H., 2005. Optimal cutpoint and its corresponding Youden index to discriminate individuals using pooled blood samples. Epidemiology, 16, 73-81.

Shiotsuki, L., Oliveira, D.P., Lôbo, R.N.B., Facó, O., 2014. Genetic parameters for growth and reproductive traits of Morada Nova sheep kept by smallholder in semi-arid Brazil. Small Ruminant Research, 120, 204-208.

Sim, J. and Wright, C.C., 2005 The Kappa statistic in reliability studies: use, interpretation and sample size requirements. Physical Therapy, $85,257-268$

Spanu, C., Berger, Y.M., Thomas, D.L., Ruegg, P.L., 2011. Impact of intramammary antimicrobial dry treatment and teat sanitation on somatic cell count and intramammary infection in dairy ewes. Small Ruminant Research, 97, 139-145.

Viera, A.J. and Garrett, J.M., 2005. Understanding interobserver agreement: the kappa statistic. Family Medicine, 37, 360-363. 